\title{
Analysis of Vegetation Density and Land Surface Temperature Using Landsat Image in the Forest Area of KPHP Unit XII Batanghari
}

\author{
Eva Achmad ${ }^{1, *}$ Rince Muryunika ${ }^{2}$ \\ ${ }^{1,2}$ Department of Forestry, University of Jambi \\ *Corresponding author. Email: evaachmad@unja.ac.id
}

\begin{abstract}
Climate change is caused by global warming due to human activities that contribute to greenhouse gas (GHG) emissions. Land-based human activities result in changes in dense vegetation, especially forest stands to land cover with low vegetation density (non-forest). Changes in land cover cause changes in surface temperature and humidity conditions. The forest area in KPHP Unit XII Batanghari has undergone significant changes in land cover over the last twenty years. This study aimed to analyse the spatial distribution of vegetation density (NDVI) and land surface temperature (LST) using remote sensing data and in this study, Landsat 8 satellite imagery was assessed. Landsat images have two thermal bands and they can be analysed to obtain information about the existing land surface temperature at the time when the earth being scanned. The results showed that the vegetation density index or NDVI ranged from 0.132 to 0.866 . The higher the NDVI value, the higher the vegetation density. The value of LST in KPHP Unit XII Batanghari varied, with a range of LST with a low temperature value of $18-25^{\circ} \mathrm{C}$, where low temperatures have land cover classes in the form of secondary forest and other vegetated areas such as plantations and agriculture. Meanwhile, high temperature values are areas with open or non-vegetated land cover classes with a temperature range of $28-52{ }^{\circ} \mathrm{C}$.
\end{abstract}

Keywords: Forest Management Unit, NDVI, LST, Landsat Image.

\section{INTRODUCTION}

Forests play a very important role in climate change mitigation efforts, by absorbing $\mathrm{CO} 2$ and turning it into an added dimension of trees. Loss of forest cover or a decrease in forest area or forest degradation causes greenhouse gas emissions so that the quality of the forest as a carbon sink also decreases.

Changes in land cover from forest to land cover classes other than forest will have an impact on ecosystem function, climate change and threats to biodiversity [1]. Vegetation can function as climate control. The role of vegetation as an absorber of solar radiation and when vegetation evaporates, it will have an impact on reducing the temperature of the environment by $5.50 \mathrm{C}-110 \mathrm{C}$. Humidity in well-vegetated areas will be higher than in areas that are rarely vegetated. This is due to the speed of wind turbulence in well-vegetated areas so that the water vapor contained in the air mass does not move quickly [2].

Many studies have described how changes in land cover affect the surface temperature of objects. The development of the area into developed land is the cause of increasing surface temperature in cities and triggering climate change [3]. Built land is not only a residential area, but roads that connect between regions trigger an increase in surface temperature. The increase in surface temperature due to the development of urban areas reaches $2.26^{\circ} \mathrm{C}$ [4] to $8^{\circ} \mathrm{C}$ [5]. The increase in temperature depends on the location, season, and area of land built up in a city. Not only can urban development determine an increase in surface temperature, changes in land cover such as paddy fields after harvesting will have higher temperatures [6],[7]. Knowing the relationship between each category of land cover and surface temperature will be useful for identifying the relationship 
between changes that have occurred [8]: [9]. This study aimed to analyse the spatial distribution of vegetation density (NDVI) and land surface temperature (LST) using remote sensing data and in this study, Landsat 8 satellite imagery was assessed.

\section{METHODS}

This research was conducted at the Production Forest Management Unit (KPHP) Unit XII Batanghari which is located at coordinates $1022^{\circ} 39 ' 29.42$ "- $103^{\circ} 27^{\prime} 56.01 "$ East Longitude and $1^{\circ} 42$ '28,40 "- $2^{\circ} 21^{\prime} 34.32$ "LS with an area of 81,149 hectares. Based on the division of government administration areas, KPHP Batanghari Unit XII is located in 3 sub-districts, namely Maro Sebo Ulu District, Bathin XXIV District and Bajubang District, Batanghari Regency.

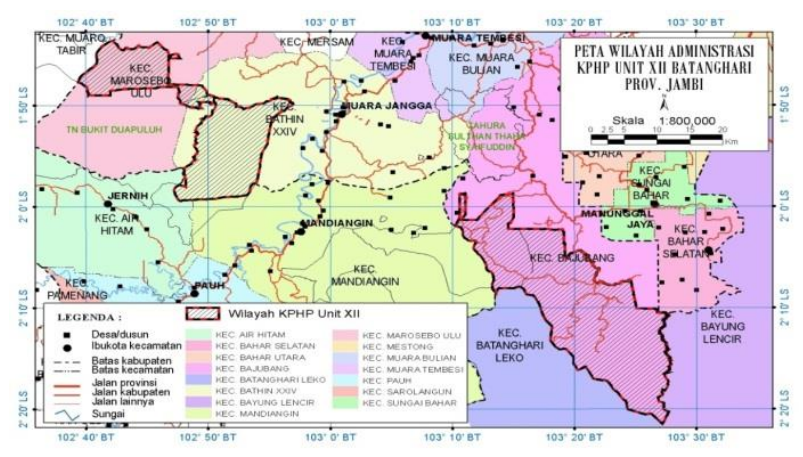

Figure 1 Location map

The research stage started with image pre-processing such as image geometric correction and geo-referencing. Land cover map was derived from Landsat image by using supervised classification. The technique of supervised classification applied was maximum likelihood method. This map then was the used as a base to stratify the location for ground check. The system used as a reference in classifying land cover types is the system of the Forestry Planning Agency (2001). The ground check point will be determined by stratified sampling and the sample was purposively determined with the consideration of accessibility factor to the points location. Other important information was also recorded in field activities such as elevation, slope, and field condition.

The Normalized Difference Vegetation Index (NDVI) is a representation of the level of greenness of vegetation. The NDVI value can be estimated from the Landsat 8 image that has been downloaded which is the same as the land cover image, NDVI analysis from Band 5 with Near-Infrared sensor and Band 4 with Red sensor with the formula: NDVI $=($ Band $5-$ Band 4$) /($ Band $5+$ Band 4).

The Normalized Difference Moisture Index (NDMI) surface moisture index is used to evaluate the different humidity of elements of a landscape. The NDMI value can be estimated from the previously downloaded
Landsat 8 imagery which can then be analysed from Band 5 with a Near-Infrared sensor and Band 6 with a ShortWave sensor. The range of NDMI values can be obtained from the results of Landsat 8 imagery processed using ArcGIS software with the formula: NDMI $=($ Band 5 Band 6) / (Band $5+$ Band 6).

Land Surface Temperature (LST) is processed from Landsat 8 imagery using bands 10 and 11 because these bands can convert the digital number obtained from the image metadata to radians and then convert it in kelvin units. Kelvin temperature values will later be converted back to centigrade units this process is done digitally. The temperature that has been obtained is entered into the diagram to see the dynamics of temperature changes that occur at KPHP Unit XII Batanghari.

Landsat 8 image processing to obtain LST was first carried out, namely converting the Digital Number with the formula $L \lambda=\mathrm{ML} * \mathrm{QCAL}+\mathrm{AL}$, after converting $\mathrm{DN}$ to TOA value, then converting the radiance value into a temperature brightness value.

\section{RESULTS AND DISCUSSIONS}

\subsection{Landcover Classification}

The land cover classification is divided into 9 land cover classes, namely secondary forest, plantation forest, plantation, agriculture, shrubs, open land, mining, water bodies and clouds which can be seen in Figure 1. Land cover classification uses visual image analysis and digital analysis. Visual analysis is done by manually grouping pixels into a class and digital analysis by automatic classification based on the brightness (brightness value / digital number) of the sample. The land cover classification uses the supervised classification method, the stage of grouping through class signatures. Determination of sample areas and classification of land cover using the maximum likelihood method.

Table 1. Landcover classification

\begin{tabular}{|l|l|}
\hline Landcover type & Area (Ha) \\
\hline Secondary forest & 17337,74 \\
\hline Plantation forest & 5609,66 \\
\hline Cloud & 599,086 \\
\hline Water body & 199,036 \\
\hline Shrubs & 3391,61 \\
\hline Plantation & 8287,88 \\
\hline Bareland & 8263,31 \\
\hline Mining & 1237,01 \\
\hline Agriculture & 36223,70 \\
\hline Total Area & $\mathbf{8 1 1 4 9 , 0 0}$ \\
\hline
\end{tabular}

The landcover map was presented in Figure 2. 


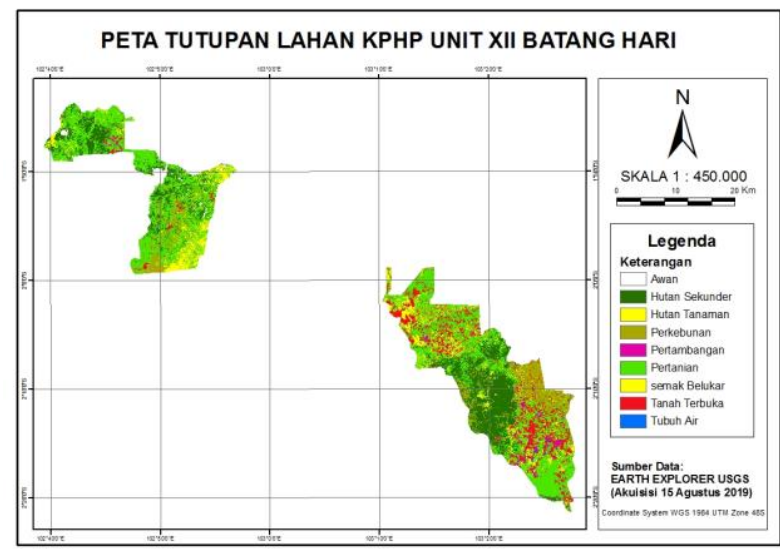

Figure 2 Landcover map

\section{$3.2 N D V I$}

The Normalized Difference Vegetation Index (NDVI) is a representation of the level of greenness of vegetation. The NDVI value can be estimated from the Landsat 8 image that has been downloaded which is the same as the land cover image, NDVI analysis from Band 5 with Near-Infrared sensor and Band 4 with Red sensor with the formula: NDVI $=($ Band $5-$ Band 4$) /($ Band $5+$ Band 4). Table 2 showed the result of NDVI calculation over KPHP unit XII Batanghari.

Table 2. NDVI of KPH Batanghari

\begin{tabular}{|l|l|}
\hline NDVI & Area (Ha) \\
\hline $0.0-0.2$ & 134.96 \\
\hline $0.2-0.4$ & 942.08 \\
\hline $0.4-0.6$ & 3964.19 \\
\hline $0.6-0.8$ & 62128.85 \\
\hline $0.8-1.0$ & 13978.94 \\
\hline Total & $\mathbf{8 1 1 4 9 , 0 0}$ \\
\hline
\end{tabular}

Figure 3 showed the map of NDVI over the area of KPHP Unit XII Batanghari.

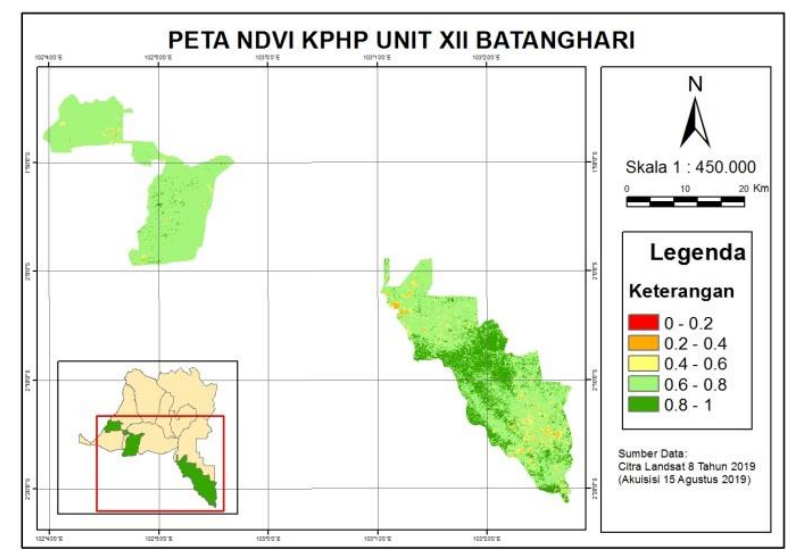

Figure 3 NDVI Map

\section{$3.3 \mathrm{NDMI}$}

The Normalized Difference Moisture Index (NDMI) surface moisture index is used to evaluate the different humidity of elements of a landscape. The NDMI value can be estimated from the previously downloaded Landsat 8 imagery which can then be analysed from Band 5 with a Near-Infrared sensor and Band 6 with a Short Wave sensor. The range of NDMI values can be obtained from the results of Landsat 8 imagery processed using ArcGIS software with the formula: $\mathrm{NDMI}=($ Band $5-$ Band 6) / (Band $5+$ Band 6).

The NDMI value obtained is then classified into 5 classes, namely <0; 0-0,008; 0.008-0.17; 0.17-0.35 and > 35 which can be seen in Figure 5.In the NDMI results the majority NDMI value at KPHP Unit XII Batanghari in 2019 is a high NDMI value, namely> 0.35 covering an area of 55,463 which can be seen in table 4 . The higher The NDMI value shows that the more humid an area in the high NDMI area on the land cover map is secondary forest and plantation land cover. Meanwhile, the low NDMI value is found in land cover, namely open land.

Table 3. NDMI KPHP Unit XII Batanghari

\begin{tabular}{|l|l|}
\hline NDMI & Area (Ha) \\
\hline$<0$ & 2227,762 \\
\hline $0-<=0.08$ & 2094,562 \\
\hline $0.081-<=0.17$ & 3313,612 \\
\hline $0.171-<=0.35$ & 17915,39 \\
\hline$>0.35$ & 55597,67 \\
\hline Total & $\mathbf{8 1 . 1 4 9}$ \\
\hline
\end{tabular}

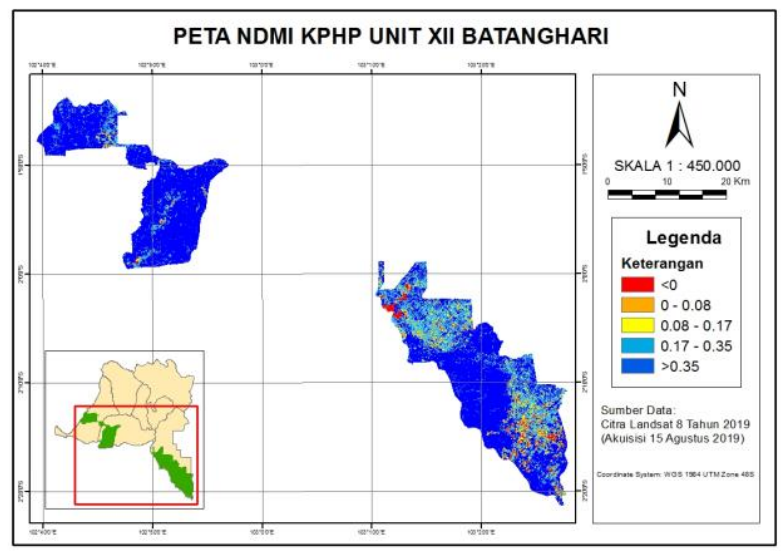

Figure 4 NDVI Map

\subsection{Land Surface Temperature}

Land Surface Temperature (LST) is processed from Landsat 8 imagery using bands 10 and 11 because these bands can convert the digital number obtained from the image metadata to radians and then convert it in kelvin units. Kelvin temperature values will later be converted 
back to centigrade units this process is done digitally. The temperature that has been obtained is entered into the diagram to see the dynamics of temperature changes that occur at KPHP Unit XII Batanghari.

Landsat 8 image processing to obtain LST was first carried out, namely converting the Digital Number with the formula $L \lambda=\mathrm{ML} * \mathrm{QCAL}+\mathrm{AL}$, after converting $\mathrm{DN}$ to TOA value, then converting the radiance value into a temperature brightness value

The majority of LST values in KPHP Unit XII Batanghari have low temperature values of $18-23^{\circ} \mathrm{C}$ which can be seen in dark blue which on the land cover map of the area has secondary forest and plantation land cover so that the densely vegetated areas have relatively low temperatures. At high temperature values, namely $28-52{ }^{\circ} \mathrm{C}$, the land cover is the area where the dominant area is open land and there is oil mining. The temperature range in KPHP Unit XII Batanghari is the lowest $18^{\circ} \mathrm{C}$ and the highest $52^{\circ} \mathrm{C}$ which can be seen in Figure 3. In the gray area at $23-24^{\circ} \mathrm{C}$ is the area of PT. REKI, whose land cover maps are forest plantations and plantations, however, have a fairly high ESG value, this is because the surrounding area is a lot of open land and there are oil mining locations, which affects the temperature in the densely vegetated secondary forest area.

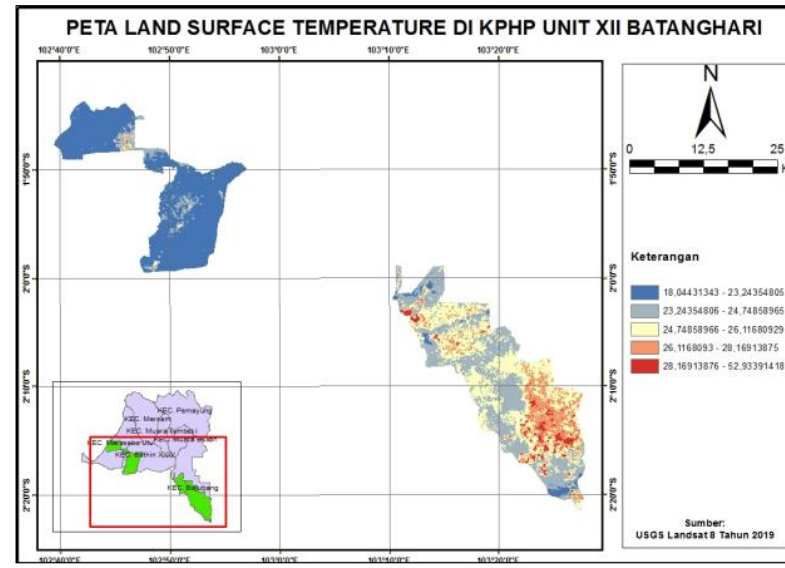

Figure 5 LST map

Spatially, in the area of high temperature is spread widely, will be accompanied by the reduction of the densely vegetated area in that area. Surface temperature and vegetation density are negatively and significantly correlated. This phenomenon shows that reduced vegetation has an impact on increasing surface temperature which in the long run can have various negative effects on the environment and humans [10].

\subsection{Discussions}

The importance of estimating the NDVI is essential since the amount of vegetation present is an important factor and NDVI can be used to infer general vegetation condition [11]. NDMI has a positive relationship with NDVI, the higher the NDVI value, the higher the NDMI value and vice versa if the NDMI value is low, the NDVI value will be lower, because dense vegetation causes humidity and water content in the environment to be higher [12].

However, NDMI and NDVI have a negative relationship with surface temperature (LST) when the NDMI and NDVI values increase, the value of the surface temperature will decrease and vice versa if the NDMI and NDVI values decrease, the value of the temperature will increase. This has to do with the ability of vegetation to regulate its temperature through evapotranspiration. The main element that regulates surface temperature is the amount of radiation absorbed and the amount of water available in an area. The temperature will increase in both vegetated and nonvegetated areas when water availability is low. The Batanghari KPHP area is an area managed based on a zoning system. Where some of the KPHP Unit XII Batanghari area has also undergone a change in land cover due to the conversion of land into plantations and settlements and the increasing number of illegal logging activities.

\section{CONCLUSIONS}

The results of research up to this stage indicate that the vegetation density index or NDVI ranges from 0.132 to 0.866 . The higher the NDVI value, the higher the vegetation density. The value of LST in KPHP Unit XII Batanghari varies, with a range of LST with a low temperature value of $18-25^{\circ} \mathrm{C}$, where low temperatures have land cover classes in the form of secondary forest and other vegetated areas such as plantations and agriculture, while high temperature values are areas with cover classes open or non-vegetated land with a temperature range of $28-52{ }^{\circ} \mathrm{C}$..

\section{AUTHORS' CONTRIBUTIONS}

The authors confirm contribution to the paper as follows: study conception and design: first and second. author; data collection: first and second author; analysis and interpretation of image analysis results: first author; draft manuscript preparation: first and second author.

\section{ACKNOWLEDGMENTS}

We would like to thank the Forestry Department Unja for funding through PNBP/Non Tax Revenue Fund scheme, LPPM UNJA and Research Team for supporting this research in the laboratory and the fieldwork as well. 


\section{REFERENCES}

[1] Southworth, 2004. An assessment of Landsat TM band 6 thermal data for analysing land cover in tropical dry forests February 2004 International Journal of Remote Sensing 25(4)DOI: 10.1080/014311603100013991 7.

[2] Destriana, 2013. Destriana . 2013. Pengaruh struktur vegetasi terhadap iklim mikro di berbagai land use di Kota Jakarta. Skripsi. Institut Pertanian Bogor. Bogor

[3] Dorigon and Amorim, 2019 Dorigon, L. P., \& Amorim, M. C. de C. T. 2019. Spatial modeling of an urban Brazilian heat island in a tropical continental climate. Urban Climate, 28, 100461.

[4] A. Nurwanda, T. and Honjo. 2020. The prediction of city expansion and land surface temperature in Bogor City, Indonesia. Sustainable Cities and Society 52.2020. https://doi.org/10.1016/j.scs.2019.101772.

[5] Liaqut et al., 2019. Liaqut, A., Younes, I., Sadaf, R., \& Zafar, H. (2019). Impact of Urbanization Growth on Land Surface Temperature using remote sensing and GIS: A Case Study of Gujranwala City, Punjab, Pakistan. International Journal of Economic and Environmental Geology, 3(9), 44-49.

[6] Al Mukmin et al., 2016; Al Mukmin, S. A., Wijaya, A. P., \& Sukmono, A. 2016. Analisis Pengaruh Perubahan Tutupan Lahan Terhadap Distribusi Suhu Permukaan Dan Keterkaitannya Dengan Fenomena Urban Heat Island. Jurnal Geodesi Undip, 5(1), 224-233.

[7] P.Sasky, Sobirin2, dan A. Wibowo. 2017. Pengaruh Perubahan Penggunaan Tanah Terhadap Suhu Permukaan Daratan Metropolitan Bandung Raya Tahun 2000 - 2016. The 8th Industrial Research Workshop and National Seminar Politeknik Negeri Bandung July 26-27, 2017

[8] Bokaie, M., Zarkesh, M. K., Arasteh, P. D., \& Hosseini, A. 2016. Assessment of Urban Heat Island based on the relationship between land surface temperature and Land Use/ Land Cover in Tehran. Sustainable Cities and Society, 23, 94-104.

[9] S.A Gorgani, M. Panahi, and F. Rezaie. 2013 The Relationship between NDVI and LST in the urban area of Mashhad, Iran. International Conference on Civil Engineering Architecture \& Urban Sustainable Development 27\&28 November 2013, Tabriz, Iran [10] Dede et.al, 2019). Dede, M, G.P Pramulatsih 1 , M.A Widiawaty, Y.R Ramadhan, A. Ati. Dinamika Suhu Permukaan Dan Kerapatan Vegetasi
Di Kota Cirebon Jurnal Meteorologi Klimatologi dan Geofisika Vol. 6 No. 1 Maret 2019

[10] Dede, M , G.P Pramulatsih 1 , M.A Widiawaty, Y.R Ramadhan, A. Ati. Dinamika Suhu Permukaan Dan Kerapatan Vegetasi Di Kota Cirebon Jurnal Meteorologi Klimatologi dan Geofisika Vol. 6 No. 1 Maret 2019

[11] Q. H. Weng, D. S. Lu, and J. Schubring, "Estimation of land surface temperature-vegetation abundance relationship for urban heat island studies," Remote Sensing of Environment, vol. 89, no. 4, pp. 467483, 2004.

[12] Achmad E, Hamzah, Albayudi dan Bima. 2018. Indeks kelembaban taman nasional bukit tiga puluh menggunakan citra satelit Landsat 8. Prosiding Seminar Nasional Geomatika 2018: Penggunaan dan Pengembangan Produk Informasi Geospasial Mendukung Daya Saing Nasional. Bogor: 5 September 2018. Hal. 425-432. 